\title{
Spiritual Crafting: Another Strategy to Transform the Meaning of Work
}

\author{
Missiliana Riasnugrahani ${ }^{1}$, Corina D. Riantoputra ${ }^{1 *}$ \\ ${ }^{1}$ Faculty of Psychology, Universitas Indonesia \\ Email: corina.r@ui.ac.id
}

\begin{abstract}
Integrating interpersonal sensemaking theory and job crafting, this qualitative study examined responses from 8 workers (consist of three white-collar, two blue-collar and three nocollar workers), to delineate the dynamic process of work meaning, defined as employees' understandings of what they do at work as well as the significance of what they do. Results indicate that meaning of work is affected by interpersonal relationships in the workplace. Being devalued by others motivate individuals to proactively shaping a new meaning to get positive regards by doing job crafting. Job crafting helps individual to forming work meaning. This means that the meaning of work is not merely a privilege of high-prestige job. A low-prestige job can have a positive meaning by doing the crafting strategies. In contrast to previous research, the researchers found that $75 \%$ of participants doing spiritual crafting. The researchers defined it as individual proactive effort to view the task as part of God's plan or will. Spiritual crafting helps the individual to accept unpleasant situations in his work, and sees the event positively. A person who has a belief that everything is part of God's plan or has a "special" purpose in his life, may experience less distress when facing barriers in the workplace. Through spiritual crafting, the individual transforms the meaning of work as the field of worship for God.
\end{abstract}

Type of Paper: Empirical

Keywords: devalued; job crafting; spiritual crafting; work meaning

\section{Introduction}

“Man's search for meaning is the primary motivation in his life." (Frankl, 2006, p. 99).

Work meaning is as important as income or job security (Hall \& Chandler, 2005). It has a stronger relationship with job satisfaction than salary (Judge et al, 2010). People who find their work meaning exceeds the financial rewards, will have less job stress, high job performance and longer tenure (Dik \& Duffy, 2009). Like Madi, a part-time worker at Black Cross officer for 27 years, explains that his daily duties are responsible for bathing abandoned corpses. During this time, he considers his duty based on human values. To him, "This work is noble, not only for making a living, but also for charity and worship" (news.liputan6.com/News/Liputan Khusus). Work meaning is defined as employees' understanding of what they do at work as well as the significance of what they do. This is related to an employees' beliefs about the function work serves in life, and is influenced by the social context (Wrzesniewski, Dutton, \& Debebe, 
2003). This definition implies that work meaning is not only formed individually, through individual perception, but also socially, through norms or shared perceptions (Pratt \& Ashforth, 2003).

Interpersonal sensemaking theory is a theory that considers the contribution of social perspective to the formation of work meaning (Rosso et al., 2010). This theory views the meaning of work dynamically, which continuously formed when individuals interact with others. People will scan for, read and interpret social cues from others, judging it as an affirming or disaffirming behavior and interpreting the degree of appreciation of others to themselves. Feelings valued or devalued by others will affect the meaning of the self, role and job that will be the source of the meaning of work. The meaning of their job, role and self depends on the need for 'self-consistency and the importance of the work domain' for people (Wrzesniewski, et al., 2003). These two forces will motivate people to change what they do and with whom they engage in work to form a coherent meaning, through job crafting (Berg, Dutton, et al., 2013).

Job crafting is an individual proactive effort to enhance a positive experience at work, and brings positive meaning to self and work by redesigning their work in meaningful ways (Wrzesniewski \& Dutton, 2001). Qualitative research on job crafting has been done on lowgrade, low-prestige occupation or 'dirty work', as it is assumed that this work lacks the specific knowledge or skills required to do job crafting (Duemmler \& Isabelle Caprani, 2016), and need to establish positive identities (Ashforth \& Kreiner, 1999; Wrzesniewski \& Dutton, 2001; Ashforth, Kreiner, Clark \& Fugate, 2007; Fuller \& Unwin, 2016). According to Ashforth and Kreiner (1999), the meaning of work is closely related to the level of work prestige. Lowprestige jobs are typically associated with low levels of education, status and income that tend to stigmatize and devaluate. Work is considered "unworthy," or less important, so that employees will have difficulty obtaining a positive job identity than high-prestige employees. To find out if employees from different level of work prestige will have different meaningmaking processes (Rosso et al., 2010), we examine different types of work and different level of work prestige.

This research also attempts to answer the challenge by Wrzesniewski and Dutton (2001), to explain the process of job crafting: how job crafting is initiated, sustained and transformed in the work process. Therefore, a qualitative approach will be used to delineate the meaningmaking process that occurs, including when the individual does the job crafting, the form and the result. We argue that the process of forming the meaning of work will be understood through a combination of interpersonal sensemaking theory and job crafting. Compared to previous research, this study focuses on process of job crafting, covering what, when and why job crafting behavior is displayed by employees of various levels of work (whitecollar, blue-collar and no-collar) and various level of work prestige (low- prestige and highprestige).

This paper is divided into four sections. First, the literature review about the interpersonal sensemaking theory and job crafting is explored. Second, the research methods used are explained. Third, results are discussed. This paper ends with the conclusion and practical implication of the study. 


\section{Literature Review}

Sensemaking process begins when individuals actively interpret social cues from others as affirming or disaffirming, valuing or devaluing what the work employee do, the roles employees hold and the people employees are. Individuals interpret cues in their work environments that directly and indirectly inform the meaning of their jobs, roles and selves in the organization. In the workplace, social cues are not only related to the task, but all the cues that are captured by them when related to others. In other words, interpersonal sensemaking theory focuses on the role of others in work and explain the 'black box' that exists between the input and output of the meaning of the work, so it can be understood how the same context and work are experienced differently among employees (Wrzesniewski, Dutton, \& Debebe, 2003).

Employees discerned and read interpersonal cues sent by others, and intrepret as valued or devalued. When employees feel devalued, they proactively enhance meaning and positive identity by doing job crafting. Job crafting is an ongoing process, that is, employees actively shape the meaning of work by crafting jobs and social environment to fit their personal goals, skills and values (Wrzesniewski \& Dutton, 2001; Berg, Wrzesniewski, et al., 2010; Wrzesniewski, et al., 2013). Meaning of jobs, roles and selves change when job crafting occurs.

Job crafting consists of cognitive crafting, task crafting and relational crafting (Berg, Dutton, et al, 2013). First of all, cognitive crafting involves changing employees' perception of tasks and relationships in their jobs (e.g., telephone operators seeing the job as an important part of getting a company project, not just receiving incoming call). Second of all, task crafting involves modifying a set of responsibilities defined by a formal job description, by adding or removing tasks, changing the nature of tasks, or determining how much time, energy, and attention is allocated to each task (e.g., a psychology lecturer who expert in statistics, offering to help his colleagues with their research statistical results). Lastly, relational crafting involves changes in how, when, or with whom employees interact in carrying out their jobs (e.g., an R \& $\mathrm{D}$ employee forming a collaborative relationship with a customer service to capture consumer needs). The three types of job crafting can perform simultaneously as a combination of all three (Petrou, Demerouti, Peeters, \& Schaufeli, 2012).

Integrating interpersonal sensemaking theory and job crafting is an attempt to understand the process of job crafting in an interpersonal context. Cues from others at workplace can be interpreted as valuing or devaluing (Dutton et al., 2012). Since people in general are motivated to create a positive self-image in their work (Wrzesniewski \& Dutton, 2001), when someone feels devalued, he or she will do job crafting as an individual mechanism to enhance meaning and positive identity in the workplace (Wrzesniewski, et al., 2013). As Dutton, Debebe and Wrzesniewski (2012) noted, work valuing is person valuing, and work devaluing is also person devaluing. Job crafting can transform a "job" into a "calling," which in turn leads to improved emotional well-being (French, 2009).

\section{Method}

To illustrate the meaning-making process, including what, when and how the individual does the job crafting, this research utilised a qualitative approach in collecting and analyzing the data. As Creswell (2007) suggests, qualitative approach is an approach that tries to understand, or interpret, phenomena in terms of the meanings people bring to them. In this study is to see 
the meanings of work.

Qualitative data was collected through semi-structured interview techniques and inductive data analysis was performed to establish patterns or themes. Face-to-face interviews were conducted to 8 employees from various company and level of work: three white-collar workers (journalists, administrative staff, and salesperson); two blue-collar workers (security guard, and cleaning service); and three no-collar workers (parking attendant, social activist, and public transport driver). Each interview took approximately one hour, and we asked for permission to record the interview process. Regarding the sample characteristic, $62.5 \%$ was male, and the mean age of the sample was 42.38 years. Furthermore, $25 \%$ had completed primary education, $50 \%$ had completed secondary education, and $25 \%$ had finished a university degree.

The researchers developed a protocol of standard questions to provide a semi-structured framework for examining the meaning-making process, which based on interpersonal sensemaking theory and job crafting. There are approximately four main questions, but the interviewer can pose follow-up questions to probe for further information. This question aims to know the individual interpretation of the interpersonal relationships experienced in the workplace and how this affects the job crafting, that is, when, how and what job crafting done by employees. The example of main questions is: (1) How others (consumers, leader, coworkers), interact or react to you? (2) What is your interpretation of the person's reaction? (3) How you handle it, so you can continue working here? (4) How you see this job? Furthermore, the interview was transcribed in verbatim, and we conducted thematic analysis to get first order and second order categorization from all participants.

\section{Results and Discussions}

This research findings fall into three major clusters. First, when and how individuals do job crafting are described. Second, what kind of job crafting the individual do is described. Finaly, why individuals do any kind of job crafting is explained. Discusion about demographic data and research implications are discussed at the end of this paper.

Meaning-making is a coping process to reduce discrepancies between situational and global meanings (Park \& Folman, 1997). The data revealed when employees feel devalued by others, they tend to do job crafting, as a proactive effort to enhance a meaning and positive identity at work (Wrzesniewski \& Dutton, 2001):

I have asked for permission to cleaning it, but he said ... "it is not necessary, it's useless anyway, because it's still (dirty) .." ... next, I was mopping in the corridor, he behaved arbitrarily ..watered the flower ... the water was spilled everywhere .. and he walked back and forth so that all the floors were dirty (disaffirming). He seemed to underestimate me, annoyed me and deliberately doing it (negative motive, devalued). (He should be grateful) now the faculty of psychology is safer .. because of my presence.. (cognitive crafting, reframing-infusing)-(cleaning service, MSS)

With tremendous threats and intimidation, they occupied the editorial room and point the fingers on me, asking for clarification of the news but with threats, harsh words and we were completely repressed, our explanation was not accepted and heard by them (disaffirming).

They do not understand press laws and prioritize emotions, so they terror, and threats us. People 
from government, council members, parties came to threaten me in front of my boss, accused me of defending my competitors or other candidates (negative motive, devalued).

Even if we are threatened, we must continue to write the news, (now) I am more careful, more accurate in writing news, upholding the principles of journalistic code of ethics. Clarification or confirmation should take precedence, cover both side, the most important is to hold on to facts and truths, do not make false news. (Task crafting-emphazising task)-(journalist, MM)

Based on the data, it can be said that job crafting behavior is done when employees experiences barriers or limits in the work. Barriers include conflicts (between people or roles), discrimination (unfair treatment/harassment), or unfavorable performance feedback (London, 1997). Employees must find ways to overcome (or not) the limitation they feel and the barriers they face, and make adaptation efforts (Berg, Wrzesniewski et al, 2010).

Responses to workplace challenges can be adaptive or maladaptive and ranging from passive acceptance, withdrawal, and sabotage, to job crafting and creative problem solving (Schabram \& Maitlis, 2016). The strong desire of individuals to see themselves positively, to feel valuable and competent through the judgment of others (Wrzesniewski, 2003), will encourage individuals to reshape the meaning of their work (Wrzesniewski, 2002) with job crafting, as part of the process of dealing with stressful situations (Park \& Folkman, 1997). Briefly it can be said that job crafting is a proactive behavior in the organization that employees do to adapt to obstacles and job limits (Berg, Wrzesniewski et al., 2010), which can be devalued actions from others.

Consistent with Wrzesniewski and Dutton (2001), when being devalued, participants demonstrated cognitive crafting (changing how employees see the job), task crafting (changing job activities by adjusting the scope of task), and relational crafting (changing the extent or nature of their relationship with others). In addition, participant also showed leisure crafting, which is defined as an initiative and proactive action to experience satisfaction and pleasure through leisure activities to meet unanswered calling inside or outside work (Berg, Grant, et al., 2010). The description of crafting types in all participants can be seen in table 1 .

The most important finding of this research is a new type of crafting done by $75 \%$ of participants namely spiritual crafting. It is an individual proactive effort to view the task as part of God's plan or will, this recognition is a form of surrender to the power of God. Religion and contemplation about the concept of God are part of many people's lives (Chan-Serafin et al, 2013), so that religiosity can direct the individual to gain meaning from his life (Steger \& Frazier's, 2005). As Davidson and Caddell (1994) point out, religion and spirituality provide the framework for people with poor jobs to convince themselves that unrewarding work is meaningful. It also provides a context, especially people with rewarding jobs, come to think that their work is sacred, spiritual, and not just secular. The following example illustrates how some of the participant perform spiritual crafting:

Sometimes there are customers who pay (and say) thanks, some do not pay, not even say thank you .... (I think) this is not my fortune ... I believe, there will be a replacement later. And it's true, after that there are customers who give one thousand, two thousand, and sometimes they give five thousand or more .. I always think like that, there will be a replacement. We have to keep serving (parking attendant, AS) 
Table 1. Crafting Behavior (Job, Leisure, Spiritual)

\begin{tabular}{|c|c|c|}
\hline Crafting & Descriptions & Sample quotes \\
\hline \multicolumn{3}{|l|}{ Cognitive crafting: } \\
\hline \multirow[t]{2}{*}{$\begin{array}{l}\text { Reframing (infusing) } \\
(\mathrm{n}=3)\end{array}$} & $\begin{array}{l}\text { Work is added with a positive } \\
\text { value, so it becomes more valuable }\end{array}$ & $\begin{array}{l}\text { Serving is the principle of this work . let's say we provide the best solution for our child .. } \\
\text { (administrative staff, D) }\end{array}$ \\
\hline & $\begin{array}{l}\text { Individuals deny the negative } \\
\text { stigma of the job. } \\
\text { "denial of responsibility" : } \\
\text { Individuals feel that he is just } \\
\text { doing the task, and someone or } \\
\text { something else is responsible for } \\
\text { things that happen. } \\
\text { "denial of injury": } \\
\text { Individuals assume that no harm } \\
\text { is done. } \\
\text { "denial of victim" : Individuals } \\
\text { argue that other people (who have } \\
\text { bad luck) deserve their fate. }\end{array}$ & $\begin{array}{l}\text { Many people comments to us ... "arrogant, overly controlled, too many rules" .. that's not what } \\
\text { we mean, but because our work has SOP to be followed. We must implement the rule (denial } \\
\text { responsibility). (Security Guard, S) } \\
\text { Many students are rude, even hit the door ... we can't do anything, we want to help but can't. } \\
\text { There are students who cry here .. not that we don't want to help, but there are academic rules that } \\
\text { must be obeyed .. there are students who understand, some do not understand .. (denial of injury, } \\
\text { Administrative staff, D) } \\
\text { Sometimes we also argue with students ... for example, student gave a sick note to the } \\
\text { department but did not get to us, so we do not know if he is sick.. then he could not take the } \\
\text { final exam. There is a sick note for two weeks .. but after that he also did not attend to college. } \\
\text { If he came only } 5 \text { from } 12 \text { lecturers so what he got? .. he said, that he will replace it by doing } \\
\text { the task ... but it can not be done, there is a rule, and student had a contract with the lecturer ... } \\
\text { (denial of victim, Administrative staff, D) }\end{array}$ \\
\hline $\begin{array}{l}\text { Recalibrating } \\
(\mathrm{n}=5)\end{array}$ & $\begin{array}{l}\text { adjusting implicit standards in } \\
\text { assessing job attributes. }\end{array}$ & $\begin{array}{l}\text { If consumers are angry, annoyed faces, we are not appreciated .. it's normal, the public } \\
\text { transportation drivers upset because we're blocking them, argue with each other ... it's normal } \\
\text {..(parking attendant, AS) }\end{array}$ \\
\hline $\begin{array}{l}\text { Refocusing } \\
(\mathrm{n}=6)\end{array}$ & $\begin{array}{l}\text { changing the focus of attention } \\
\text { from stigmatization to } \\
\text { nonstigmatization. }\end{array}$ & $\begin{array}{l}\text { I met with my friends, they asked. "Why you cleaning the toilet? What is the benefit of your } \\
\text { school?" I replied .. the important things, my job is legal .. I have income, not stealing or } \\
\text { muggle..(cleaning service, MSS) }\end{array}$ \\
\hline \multicolumn{3}{|l|}{ Task crafting : } \\
\hline $\begin{array}{l}\text { Adding } \\
(\mathrm{n}=1)\end{array}$ & $\begin{array}{l}\text { Employees add tasks they deem } \\
\text { important in their work. }\end{array}$ & $\begin{array}{l}\text { I watch every motorcycle parked here. I help consumers who have difficulty with their shopping } \\
\text { goods .. if the consumer brings a lot of stuff, I help tie the goods, so that all goods can fit on } \\
\text { his motorcycle, There also consumers who forget to take their keys, HP, or wallet, I take and } \\
\text { secured it. We sell services, we give good service to them, so people more trust with us .... } \\
\text { (Parking attendant, AS) }\end{array}$ \\
\hline $\begin{array}{l}\text { Emphasizing } \\
(\mathrm{n}=3)\end{array}$ & $\begin{array}{l}\text { Employees allocate more time, } \\
\text { energy, and attention to tasks they } \\
\text { deem important }\end{array}$ & $\begin{array}{l}\text { Actually the most exciting task is while in the field, but being a journalist coordinator is an } \\
\text { assignment then I have to accept it, and enjoy it. To improve my writing skills, and to sharpen } \\
\text { my observations on current issues I write "Tajuk" columns once a week. (Journalist, MM) }\end{array}$ \\
\hline $\begin{array}{l}\text { Redesigning } \\
(\mathrm{n}=1)\end{array}$ & $\begin{array}{l}\text { Employees redesign existing tasks } \\
\text { to be more meaningful. }\end{array}$ & $\begin{array}{l}\text { When customer comes, I notice that this consumer brought this bike. If they come, I go straight } \\
\text { to the motorcycle ... I often forget to keep the helmet when moving the motorcycle, in order to } \\
\text { remember it, I immediately take it or tied on the motorcycle (Parking attendant, AS) }\end{array}$ \\
\hline \multicolumn{3}{|l|}{ Relational crafting : } \\
\hline $\begin{array}{l}\text { Building relationship } \\
(\mathrm{n}=2)\end{array}$ & $\begin{array}{l}\text { Building relationships with others } \\
\text { who can cultivate pride, dignity, or } \\
\text { self-esteem }\end{array}$ & $\begin{array}{l}\text { Everyday I offer people to buy a product or become my downline. I have few friends, so I'm } \\
\text { looking for new acquaintances. If they refuse my offer, or my message is not replied, I look for } \\
\text { someone else.. I am more daring because only offer products through chating .. (salesperson, } \\
\text { LS) }\end{array}$ \\
\hline $\begin{array}{l}\text { Reframing relationship } \\
(\mathrm{n}=1)\end{array}$ & $\begin{array}{l}\text { Changing the nature of the } \\
\text { relationship to gain meaningful } \\
\text { purpose }\end{array}$ & $\begin{array}{l}\text { I have to continue this work .... a month or two months later the conditions are more } \\
\text { comfortable... the more familiar with the TKT and lecturers, then the feelings of affection will } \\
\text { arise. Just like the old man said.. 'the more we know, the more we love it'. Now it's more } \\
\text { comfortable for us......(security guard, S) }\end{array}$ \\
\hline $\begin{array}{l}\text { Adapting relationship } \\
(\mathrm{n}=3)\end{array}$ & $\begin{array}{l}\text { Provide help and support to others } \\
\text { in the work, to encourage others to } \\
\text { do the same. Enhance mutual trust, } \\
\text { positive attention, and vitality. }\end{array}$ & $\begin{array}{l}\text { It's hard for people to accept me, so my strategy is to approach the kids .. I play with them, } \\
\text { write in ground, pretend to trade, so the children are happy ... when I know and love his son } \\
\text { sincerely, I will know his mother, if I know his mother, I will know his father, and finally I will } \\
\text { be accepted into one family. One family must know another family, just like that, as the cell } \\
\text { continues to divide. (social activist, P) }\end{array}$ \\
\hline \multicolumn{3}{|l|}{ Leisure crafting } \\
\hline $\begin{array}{l}\text { Additional calling } \\
(\mathrm{n}=1)\end{array}$ & $\begin{array}{l}\text { View their current occupation as } \\
\text { a calling, and have one or more } \\
\text { unanswered callings, and pursue it } \\
\text { in leisure time }\end{array}$ & $\begin{array}{l}\text { My other activity is "heritage community". Too bad if my knowledge is not utilized. I am quite } \\
\text { successful in getting people to learn history in a fun way. For me this activity is useful, stress } \\
\text { can be reduced by exploring and increasing knowledge in the field of history (Journalist, MM) }\end{array}$ \\
\hline $\begin{array}{l}\text { Missed calling } \\
(\mathrm{n}=1)\end{array}$ & $\begin{array}{l}\text { Do not view their current } \\
\text { occupation as a calling, but have } \\
\text { one or more unanswered callings } \\
\text { and pursue it in leisure time }\end{array}$ & $\begin{array}{l}\text { I have another mission, so I keep on praying. God, I want to work as a lecturer, because of } \\
\text { flexible working hours, so I can join the church service by visiting the families who have } \\
\text { problems, so as not to get divorced .. if God allows me to serve in this field, I want to serve } \\
\text { fully. (Administrative staff, D) }\end{array}$ \\
\hline $\begin{array}{l}\text { Spiritual crafting } \\
(\mathrm{n}=6)\end{array}$ & $\begin{array}{l}\text { Acknowledge and surrender to } \\
\text { God's will or plan }\end{array}$ & $\begin{array}{l}\text { Life should be grateful and enjoyed, do not complain, or have many desires. Everyone already } \\
\text { has their own destiny .. though I want to be rich, but if its fate as it is now, it will still be. Allah } \\
\text { created man with his own destiny, there is fate from Allah, so do not be surprised (driver of } \\
\text { public transportation, AS) }\end{array}$ \\
\hline
\end{tabular}


People who have a permanent job are still confused to meet the needs, while I was not confused (although I do not have a permanent job), because I fully believe (in God) and I always have income. I can pay electricity and water bills. I can feed to everyone who comes to my house . (though) I do not have savings (Social activist, P)

From the examples, it appears that while experiencing devalued in the workplace, the individual views everything that happens as an intervention of the greater 'power', that is God. This effort helps the individual to accept unpleasant situations in his work, and sees the event as positive. The spiritual influence on work is also examined by Neubert and Halbesleben (2015), that spirituality becomes buffering when the individual does not feel job satisfaction. Park and Folkman (1997), noted that strong religious beliefs make some people able to perceive stressful situations as challenges rather than threats. Someone who have belief that everything is part of God's larger plan or everything has a best purpose, is more resilient than a person who does not have this view. Similar with this, Karakas (2010) found workers who can express their spirituality through their work, finding their work more satisfying and meaningful and performing better. Hence, it can be said that spiritual crafting becomes a strategy to handle stress for individuals when experiencing unpleasant things in the workplace, as revealed by S, and MSS.

Sometimes I feel (lazy, saturated)... but I do not follow the feelings because I always think, my child must go to school, and family's needs must remain fulfilled .. many people do not have a jobs .. Too arrogant if I do not grateful for being given this job. I am grateful for that, because until now I'm still healthy and my children can go to school ... (security guard, S)

I still meet with my friends, and they still ask ... "still doing the same job?" .. Yes, I said ... "why stay in this job?" This is all I can do, have applied for another job, but maybe this is my "destiny" ... But now I'm more confident, because I already comfortable with the job. I have the intention that any kind of work, I intend as worship (cleaning service, MSS)

Spiritual crafting seems to be related to the level of work prestige. As shown in table 2, it appears that individuals at all low-prestige jobs felt perceived barriers in their job selection, in contrast to high-prestige jobs that can choose work based on internal forces. Perceived barriers are perceptions of limited ability to choose other jobs due to lack of work alternatives, limitations of socio-economic backgrounds such as education, economics or age. While the internal force is the inner strength that drives people to pursue their work, which can be an interest or aspiration they have for a long time. This is consistent with Blustein's theory (2013), that frequently individuals cannot choose the work they want, because of the social and economic constraints they experience, and low-prestige occupations are usually tend to stigmatize and devaluate (Ashforth \& Kreiner,1999). This condition encourages individuals to do spiritual crafting to find a positive meaning at work.

Spiritual crafting is done when the individual feels a very strong barrier, and is logically unexplained. As revealed by Park dan Folkman (1997), some events, which are too aversive or extreme, are difficult to be fitted into existing beliefs, even with reappraisals. Therefore, the discovery of meaning in adverse events is often a religious conversion, re-realizing that there is God's power in life. Religious conversions are another way of coping, when the usual way is no longer effective. As Silberman (2005) notes, that in the most difficult situations, which can not be solved through problem-solving strategies, religion becomes a powerful source of meaning for the individual. 
Table 2. Comparison of crafting types on job selection and level of work prestige

\begin{tabular}{lcccc|cccc}
\hline \multirow{2}{*}{ Crafting Types } & \multicolumn{4}{c}{ Low-prestige jobs } & \multicolumn{4}{c}{ High-prestige jobs } \\
\cline { 2 - 10 } & PB & IF & PB-EF & IF-EF & PB & IF & PB-EF & IF-EF \\
\hline Cognitive crafting & 2 & - & 2 & - & - & 1 & - & 2 \\
\hline Task crafting & 1 & - & - & - & - & - & - & 1 \\
\hline Relational crafting & 1 & - & 1 & - & - & 2 & - & 1 \\
\hline Leisure crafting & - & - & - & - & - & - & - & 2 \\
\hline Spiritual crafting & 2 & - & 2 & - & - & 1 & - & 1 \\
\hline Note $: \mathrm{n}=$ number of interviewees who mentioned the relevant crafting \\
PB = perceived barriers; IF = internal forces; EF = external forces
\end{tabular}

Table 3. Types of crafting, level of work prestige and types of collar

\begin{tabular}{|c|c|c|c|c|}
\hline \multirow[t]{2}{*}{ Crafting Types } & \multicolumn{2}{|c|}{ Low-prestige jobs $(\mathrm{n}=4)$} & \multicolumn{2}{|c|}{ High-prestige jobs $(n=4)$} \\
\hline & Blue-collar $(\mathrm{n}=2)$ & No-collar $(\mathrm{n}=2)$ & White-collar (n=3) & No-collar $(\mathrm{n}=1)$ \\
\hline \multicolumn{5}{|l|}{ Cognitive crafting } \\
\hline Reframing (infusing) $(\mathrm{n}=3)$ & 1 & 1 & 1 & - \\
\hline Reframing (neutralizing) $(n=4)$ & 1 & 1 & 2 & - \\
\hline Recalibrating $(\mathrm{n}=5)$ & 2 & 2 & 1 & - \\
\hline Refocusing $(\mathrm{n}=6)$ & 2 & 2 & 2 & - \\
\hline \multicolumn{5}{|l|}{ Task Crafting } \\
\hline Adding $(\mathrm{n}=1)$ & - & 1 & - & - \\
\hline Emphasizing $(\mathrm{n}=3)$ & - & 1 & 2 & - \\
\hline Redesigning $(\mathrm{n}=1)$ & - & 1 & - & - \\
\hline \multicolumn{5}{|l|}{ Relational crafting } \\
\hline Building relationship $(\mathrm{n}=2)$ & - & - & 2 & - \\
\hline Reframing relationship $(\mathrm{n}=1)$ & 1 & - & - & - \\
\hline Adapting relationship $(\mathrm{n}=3)$ & - & 1 & 1 & 1 \\
\hline \multicolumn{5}{|l|}{ Leisure Crafting } \\
\hline Additional calling $(\mathrm{n}=1)$ & - & - & 1 & - \\
\hline Missed calling $(\mathrm{n}=1)$ & - & - & 1 & - \\
\hline Spiritual crafting $(\mathrm{n}=6)$ & 2 & 2 & 1 & 1 \\
\hline
\end{tabular}

In addition to table 2, it is also seen that spiritual crafting is performed by individuals who recognize the existence of an external force, or 'the divine intervention' (spiritual force). Maybe this happens because from the beginning of job selection, the individual has realized that his 'placement' in the work is inseparable from the power of God, so when the individual feels devalued, he will recall his belief to develop a positive meaning in work. In line with Chan-Serafin et al, (2013), when faced with threat, the highly intrinsic religious participants were more likely to engage in self-protective cognitions and see themselves in a more positive but unrealistic light (i.e., self-deception). This condition occurs because religious beliefs are relatively stable, people are more likely to change their perceptions of situations to fit their religious beliefs than to change those beliefs (Park \& Folkman, 1997).

Spiritual individuals can find meaning by linking their work to the divine, giving them the feeling that they are contributing to a higher power than themselves (Lips-Wiersma, 2002). Linking to the divine, is also self-abnegation, which is deliberately subordinating oneself to something external to and/or larger than the self, to seek greater control over one's fate or environment control, to reduce practical and existential anxieties (Rosso et.al, 2010).

Table 3 show that each employee group performs a different type of job crafting. Low-prestige employees use more cognitive crafting than high-prestige employees, and blue-collar is the only group that can not do task crafting. Both may be due to the specific characteristics of this work.

In low-prestige groups, almost all employees tend to feel perceived barriers in job selection (table 2), they also feel a negative stereotype of their work, because low-prestige jobs tend to 
stigmatize and devaluate (Ashforth \& Kreiner,1999). This strong social pressure tends to limit employees'opportunities for task and relational crafting, but still possible to do cognitive crafting (Berg et. al, 2013). Thus, cognitive crafting is probably the most effective type of crafting for low-prestige jobs in overcoming strong barriers, because cognitive crafting is more a kind of avoidance coping. People do not really shape their jobs but rather adjust their perspective on those work conditions that do not fit with their needs, abilities and preferences (Tims \& Bakker, 2010). In short it can be said that cognitive crafting is crafting the job cognitively so that it is suited better to oneself (Niessen, 2016)

While in the blue-collar group, the characteristics of their work tend to be operational, have strict rule and low autonomy to modify tasks. Wrzesniewski and Dutton (2001), state that job autonomy as an important prerequisite of proactive behaviors, provide opportunities to change task and social boundaries. The degree of autonomy in work is related to task crafting which is giving individuals more freedom to determine their work procedures and to schedule their tasks (Niessen, 2016). Similar with this, Berg et. al, (2013) argue that not all jobs and situations are conducive to job crafting, some job structures have strict rule and rigid procedures that must be obeyed, and these situations may limit task and relational crafting. Effort to craft their jobs may results in punishment, because companies demand that work be done in a certain way. As Niessen (2016), noted, that cognitive crafting behavior is more likely to be done in rigid situations because crafting cognitive is less effortful, and less risky, compared to behaviors that alter actual tasks and relationships at work. Therefore, for this reason, blue-collar worker can't do task crafting but only cognitive crafting. In contrast to the blue-collar, the no-collar worker can still do task crafting, even though they are classified as low-prestige level (table 3), because they are not tied to a organization so they have full freedom to modify the task.

The next finding in this study is that only a white-collar employee is doing leisure crafting when they feel devalued (table 3). As Berg, et al. (2010) points out, leisure crafting is an initiative and proactive action to experience satisfaction and pleasure through leisure activities to meet unanswered calling inside or outside of work. In both white-collar participants, they feel the calling, but only one person who feels the current job as calling. This is consistent with the theory of Berg et al., (2010), that unanswered calling is divided into additional calling and missed calling. They both have unanswered calling outside the work, but the additional calling feels that the current job as calling, while the missed calling person does not, so the pursuit of a missed call is meant to compensate for his work (Petrou, Barker \& Van den Heuvel, 2016).

The existence of unanswered calling on the white-collar employees can be due to the degree of job autonomy and level of education in both participants. White-collar worker has a higher authority to modify the task, and this freedom provides an opportunity to respond to unanswered calling (Wrzesniewski and Dutton 2001), the more autonomous the work, the more flexible it is in responding to unanswered calling (Berg et.al, 2010). In addition, the level of education of both participants is bachelor, which tends to have higher cognitive ability than other participants' education level. Employees who can perform flexible crafting behaviors tend to have adequate cognitive abilities, because it affects perceptions of situations and how individuals handle situations, including in handling adversity or challenges (Van den Heuvel, Demerouti, Bakker, \& Schaufeli, 2010). Based on this research, a new theoretical framework was constructed, as illustrated in Figure 1. 


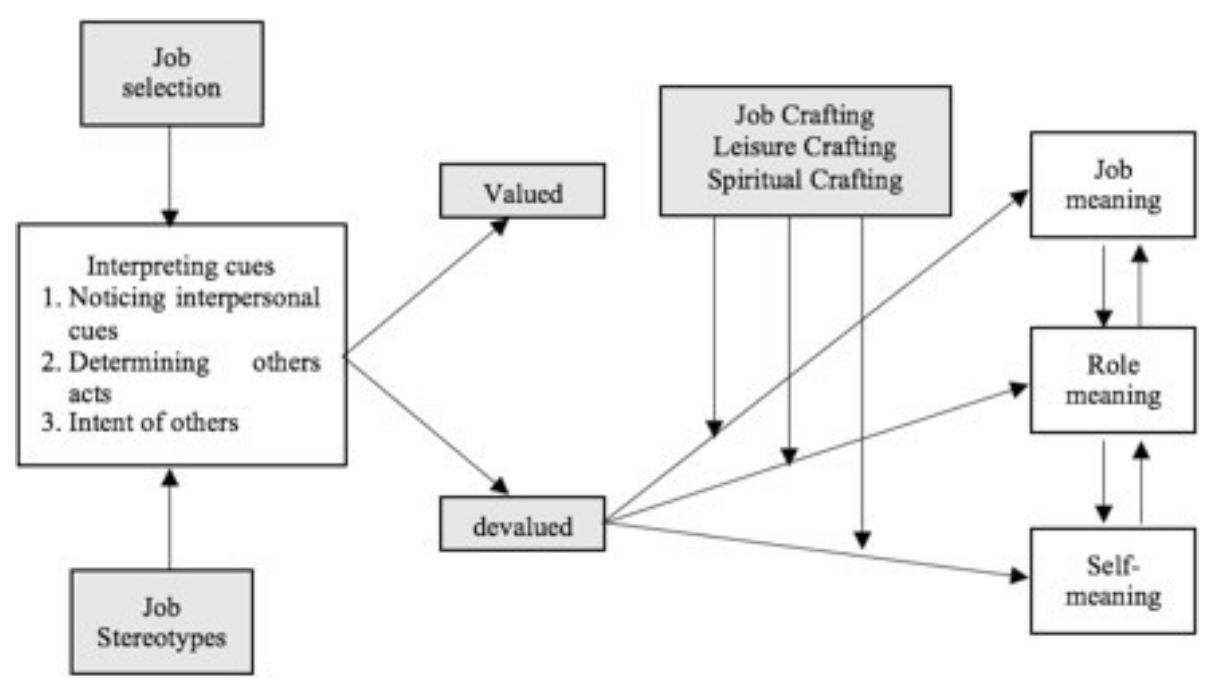

Figure 1. The process of forming the meaning of the work

\section{Conclusion}

This study shows that the meaning of work can be explained through the theory of interpersonal sensemaking (Wrzesniewski et.al., 2003), and job crafting (Wrzesniewski \& Dutton, 2001). Every employee will always be valued and devalued when interacting in the work environment. When an individual feels devalued, he or she will perform crafting behavior or even spiritual crafting, in order to obtain a positive work meaning. Spiritual crafting is the individual's proactive endeavor to view the task as part of God's will and plan, and also surrender to the power of God.

Future research needs to be done to see the relationship between spiritual crafting and other types of job crafting. For managerial implications, organizations need to give employees the opportunity to do job crafting by giving autonomy and trust to employees, so that employees can find the meaning of work.

\section{References}

Ashforth \& Kreiner. (1999). “'How Can You Do It?': Dirty Work and the Challenge of Constructing a Positive Identity," The Academy of Management Review 24(3): 413-434.

Ashforth, B. E., Kreiner, G. E., Clark, M. A., \& Fugate, M. (2007). Normalizing dirty work: Managerial tactics for countering occupational taint. Academy of Management Journal, 50(1), 149-174. https://doi.org/10.5465/AMJ.2007.24162092

Berg, J. M., Grant, A. M., \& Johnson, V. (2010). When callings are calling: Crafting work and leisure in pursuit of unanswered occupational callings. Organization Science, 21(5), 973-994. 
Berg, J. M., Wrzesniewski, A \& Dutton, J. E. (2010). Perceiving and responding to challenges in job crafting at different ranks: When proactivity requires adaptivity. Journal of Organizational Behavior. 31, 158-186

Berg, J. M., Dutton, J. E., \& Wrzesniewski, A. (2013). Job crafting and meaningful work. In B. J. Dik, Z. S. Byrne \& M. F. Steger (Eds.), Purpose and meaning in the workplace (pp. 81-104). Washington, DC: American Psychological Association.

Blustein, D. L. (2013). The psychology of working: A new perspective for a new era. In D. L. Blustein (Ed.), Oxford handbooks online. Retrieved from http://www.oxfordhandbooks. com/view/http://dx.doi.org/10.1093/oxfordhb/9780199758791.001.0001/oxfordhb9780199758791-e-001

Chan-Serafin, S., Brief, A. P., \& George, J. M. (2013). How does religion matter and why? Religion and the organizational sciences. Organization Science. http://dx.doi. org/10.1287/orsc.1120.0797.

Creswell, J.W. (2007). Qualitative inquiry and research design : Choosing among five approach (2nd ed.). Thousand Oaks, CA: SAGE

Davidson, J. C., \& Caddell, D. P. (1994). Religion and the meaning of work. Journal for the Scientific Study of Religion, 33, 135-147, http://dx.doi.org/ 10.2307/1386600.

Dik, B. J., \& Duffy, R. D. (2009). Calling and vocation at work: Definitions and prospects for research and practice. The Counseling Psychologist, 37, 424-450, http://dx.doi.org/ $10.1177 / 0011000008316430$.

Duemmler, K., \& Caprani, I. (2017). Identity strategies in light of a low-prestige occupation: the case of retail apprentices. Journal of Education and Work, 30(4), 339-352.

Dutton, Debebe \& Wrzesniewski. (2012). Being Valued and Devalued At Work: A Social Valuing Perspective. Qualitative Organizational Research: Best Papers from the Davis Conference on Qualitative Research, Volume 3, Information Age Publishing.

Frank1, V. E. (2006). Man's search for meaning. Boston, MA: Beacon Press.

French, M. (2009). Job crafting. In R. Watkins \& D. Leigh (Eds.), Handbook of Improving Performance in the Workplace, Volume 2, The Handbook of Selecting and Implementing Performance Interventions. San Francisco, CA: Pfeffer

Fuller, A., \& Unwin, L. (2017). Job Crafting and Identity in Low-Grade Work: How Hospital Porters Redefine the Value of their Work and Expertise. Vocations and Learning. https:// doi.org/10.1007/s12186-017-9173-z

Hall, D., \& Chandler, D. (2005). Psychological success: When the career is a calling. Journal of Organizational Behavior, 26, 155-176. 
Judge, T. A., Piccolo, R. F., Podsakoff, N. P., Shaw, J. C., \& Rich, B. L. (2010). The relationship between pay and job satisfaction: A meta-analysis of the literature. Journal of Vocational Behavior, 77(2), 157-167.

Karakas, F. (2010). Spirituality and performance in organizations: A literature review. Journal of business ethics, 94(1), 89-106.

Lips-Wiersma, M. (2002). The influence of spiritual "meaning-making" on career behavior. Journal of Management Development, 21(7), 497 - 520

London, M. (1997). Overcoming career barriers: A model of cognitive and emotional processes for realistic appraisal and constructive coping. Journal of Career Development, 24(1), 25 38 .

Neubert, M.J, \& Halbesleben, K. (2015). Called to Commitment: An examination of relationships between spiritual calling, job satisfaction, and organizational commitment. Journal Business Ethics. 132, 859-872, http://dx.doi.org/10.1007/s10551-014-2336-z

Niessen, C., Weseler, D., \& Kostova, P.(2016). When and why do individuals craft their jobs? The role of individual motivation and work characteristics for job crafting. human relations, 69(6), 1287-1313.

Park, C. L., \& Folkman, S. (1997). Meaning in the context of stress and coping. Review of general psychology, 1(2), 115.

Petrou, Bakker \& Heuvel. (2016). Weekly job crafting and leisure crafting: Implication for meaning-making and work engagement. Journal of Occupational and Organizational Psychology, http://dx.doi.org/10.1111/joop.12160

Petrou, P., Demerouti, E., Peeters, M. C. W., \& Schaufeli, W. B. (2012). Crafting a job on a daily basis: Contextual correlates and the link to work engagement. Journal of Organizational Behavior, 33, 1120-1141.

Pratt, M. G., \& Ashforth, B. E. (2003). Fostering meaningfulness in working and at work. In K. S. Cameron, J. E. Dutton, \& R. E. Quinn (Eds.), Positive organizational scholarship (pp. 309-327). San Francisco: Berrett-Koehler Publishers, Inc.

Rosso, B. D., Dekas, K. H., \& Wrzesniewski, A. (2010). On the meaning of work: A theoretical integration and review. Research In Organizational Behavior, 30, 91-127.

Schabram \& Maitlis. (2016). Negotiating the Challenges of A Calling: Emotion and Enacted Sensemaking in Animal Shelter Work. Academy of Management Journal Steger, M., \& Frazier, P. (2005). Meaning in life: One link in the chain from religiousness to wellbeing. Journal of Counseling Psychology, 52, 574-582.

Silberman, I. (2005), Religion as a Meaning System: Implications for the New Millennium. Journal of Social Issues, 61: 641-663. doi:10.1111/j.1540-4560.2005.00425.x 
Steger, M., \& Frazier, P. (2005). Meaning in life: One link in the chain from religiousness to well-being. Journal of Counseling Psychology, 52, 574-582.

Tims, M., \& Bakker, A. B. (2010). Job crafting: Towards a new model of individual job redesign. SA Journal of Industrial Psychology, 36(2), 1-9.

Van den Heuvel, M., Demerouti, E., Bakker, A. B., \& Schaufeli, W. B. (2010). Personal resources and work engagement in the face of change. Contemporary occupational health psychology: Global perspectives on research and practice, 1, 124-150.

Wrzesniewski, A., McCauley, C., Rozin, P., \& Schwartz, B. (1997). Jobs, careers, and callings: People's relations to their work. Journal of Research in Personality, 31, 21-33, http:// dx.doi.org/10.1006/jrpe.1997.2162.

Wrziesniewski, A \& Dutton (2001). Crafting A Job : Revisioning employees as active crafters of their work. The Academy of Management Review, 26(2), 179-201

Wrzesniewski, A. (2002). It's not just a job: Shifting meanings of work in the wake of 9/11. Journal of Management Inquiry, 11, 230-234.

Wrzesniewski, A., Dutton, J. E., \& Debebe, G. (2003). Interpersonal sensemaking and the meaning of work. Research in Organizational Behavior, 25, 93-135.

Wrzesniewski, Lobuglio, Dutton \& Berg. (2013). Job Crafting and cultivating positive meaning and identity in work. Advances in Positive Organizational Psychology, Volume 1, 281302. 